\title{
Ecosystem Based Adaptation: Concept and Terminology in Strategic Adaptation Planning (Municipal and Inter-Municipal) in Portugal
}

\author{
Ana Cousiño* $*$ and Gil Penha-Lopes
}

check for updates

Citation: Cousiño, A.; Penha-Lopes, G. Ecosystem Based Adaptation: Concept and Terminology in Strategic Adaptation Planning (Municipal and Inter-Municipal) in Portugal. Sustainability 2021, 13, 6145 . https://doi.org/10.3390/ su13116145

Academic Editors: Alessandra De Marco and Jeroen Meersmans

Received: 16 March 2021

Accepted: 26 May 2021

Published: 29 May 2021

Publisher's Note: MDPI stays neutral with regard to jurisdictional claims in published maps and institutional affiliations.

Copyright: (c) 2021 by the authors. Licensee MDPI, Basel, Switzerland. This article is an open access article distributed under the terms and conditions of the Creative Commons Attribution (CC BY) license (https:/ / creativecommons.org/licenses/by/ $4.0 /)$.
Centre for Ecology, Evolution and Environmental Changes (cE3c), Faculdade de Ciências da Universidade de Lisboa, Campo Grande, Bloco C2, Piso 5, 1749-016 Lisbon, Portugal; gppenha-lopes@fc.ul.pt

* Correspondence: ana.rez.cousino@gmail.com

\begin{abstract}
Ecosystem-based adaptation $(\mathrm{EbA})$ is a nature-based solution that has gained importance in the context of international climate policy, such as in the EU Adaptation Strategy (2013), which explicitly encourages its adoption and which should continue in The European Green Deal. This study aims to analyze how the EbA concept has been adopted in strategic adaptation planning at the municipal and intermunicipal levels in Portugal after the publication of the European adaptation strategy in 2013. Thus, a quantitative content analysis was carried out, based on EbA keywords, of municipal strategies and intermunicipal plans in Portugal. The term "ecosystem-based" has not been transposed as an explicit objective at the municipal and intermunicipal levels. All strategies and plans have included indirect references to the underlying elements of the EbA concept. This study highlights that although the EU Adaptation Strategy explicitly encourages EbA, this does not mean that it is adopted as a preferred adaptation approach at the local level in Portugal. The EbA seems to be more widely understood by the research community than by municipal technicians or private companies. It is necessary to explore how the EbA concept can be more widely accepted through the generation of co-benefits and by synergies between topics.
\end{abstract}

Keywords: ecosystem-based adaptation (EbA); strategic planning of adaptation; climate change; biodiversity; ecosystem service; nature-based solution

\section{Introduction}

Ecosystem-based adaptation (EbA) is defined as the use of biodiversity and ecosystem services to help people adapt to climate change impacts [1]. EbA is closely related to Community-based Adaptation ( $\mathrm{CbA}$ ), "a community-led process, based on communities' priorities, needs, knowledge and capacities, which should empower people to plan for and cope with the impacts of climate change" [2] (p. 13) and is influenced by an earlier concept, Ecosystem-based Management (EbM), a management approach that tries to balance objectives, such as the sustainable use of resources, guaranteeing equal access to resources and reaching objectives conservation [3].

$\mathrm{EbA}$ approach is referred to as a flexible, economical and widely applicable approach [4], capable of dealing with the magnitude, speed and uncertainty of climate change [5]. In addition, there are references that EbA can potentially provide multiple economic, social and environmental co-benefits [4].

The EbA concept appears in the international political arena by the United Nations Framework Convention on Climate Change in 2008. Since then, it has become an important aspect in the international climate policy framework, it is the case with the EU climate adaptation strategy [6], which explicitly encourages the adoption of ecosystem-based adaptation approaches. This trend will tend to continue in the new EU strategy on adaptation to climate change as mentioned in The European Green Deal "Climate adaptation work must continue to influence public and private investments, including solutions based on 
nature" [7] (p. 5). Solutions based on nature are solutions that are inspired and supported by nature, which are cost-effective, simultaneously provide environmental, social and economic benefits and help build resilience. Such solutions bring nature, natural features and processes into cities, landscapes and seascapes, through locally adapted, resourceefficient and systemic interventions [8]. EbA is a nature-based solution to deal with the impacts of climate change, focuses on the benefits that humans derive from biodiversity and ecosystem services, and how these benefits can be used in the face of climate change [9].

The EU adaptation strategy paved the way for the Member States and municipalities to design and implement strategies for adapting to climate change [6]. In this sense, several municipalities in Portugal have been designing and implementing adaptation strategies [10] in order to better deal with the impacts of climate change at the local level. More recently, municipalities have joined freely in intermunicipal entities that have been developing their strategic adaptation plans.

Municipal planning represents a key way to integrate adaptation actions [11]. It is at the local level that the establishment of adaptation strategies focused on dealing with regional impacts will provide tangible benefits for local residents [12]. In this sense, climate change adaptation strategies have been considered in local planning, for example, in European cities [13]. However, in relation to EbA, specific references and knowledge about its integration into local adaptation planning are still poorly documented [14,15]. In addition, EbA is often not systematized or labeled as such [16].

Knowing the use and acceptance of the concept of EbA in local strategic planning is essential to promote its implementation effectively. Thus, taking into account the objective of the EU's adaptation strategy (2013), we sought to analyze the use of the EbA concept in municipal strategies and in inter-municipal plans for adapting to climate change, answering the following questions:

1. How is the EbA concept referred to in the strategies and plans?

2. What are the thematic sections of the strategies and plans that refer to the EbA concept?

Based on this analysis, we seek to infer whether the concept of EbA advocated by European policy has been adopted in strategic adaptation planning. In this sequence, we try to provide some ideas to strengthen the explicit adoption of the concept of $\mathrm{EbA}$ in strategic adaptation planning at the local and sub-regional levels.

\section{Materials and Methods}

To answer the questions raised, a quantitative content analysis [17] based on keywords related to the EbA concept was used. The documentation used for the analysis were municipal strategies, intermunicipal plans for adaptation to climate change in Portugal and the European Strategy for adaptation on climate change (2013).

\subsection{Selection of Documents to Be Analyzed}

The documents analyzed were the first municipal strategies (2015-2016) and the first intermunicipal plans for adapting (2017-2019) to climate change carried out after the publication of the EU Adaptation Strategy in 2013. This selection is the result of the policy change in financing where the elaboration of intermunicipal plans was prioritized instead of municipal strategies.

The research focused on the analysis of municipal strategies (EMAAC, acronym in Portuguese) and intermunicipal plans (PIAAC, acronym in Portuguese) for adaptation to climate change in Portugal in comparison with the European adaptation strategy (2013). In this sense, the 27 municipal strategies carried out under the ClimAdapt.Local project (2015-2016) (https://www.adapt-local.pt/, accessed on 16 February 2021) and the six intermunicipal plans publicly available online (2017 to 2019) were selected. The consortium responsible for ClimAdaPT.Local is led by the CCIAM/cE3c research center at the Faculty of Sciences of the University of Lisbon and consists of Portuguese and Norwegian entities (academics, companies, NGOs and municipalities). 
The municipal strategies followed a basic methodology called ADAM (Support for Decision on Municipal Adaptation) that guided its elaboration. The ADAM methodology was fully developed within the scope of the ClimAdaPT.Local project and was specially adapted to the Portuguese reality based on the model developed by the UKCIP (https: / / www.ukcip.org.uk/, accessed on 16 February 2021) (UK Climate Impacts Program). This methodology is composed of six interrelated steps forming a strategic development cycle: 0 . Prepare the work; 1 . Identify current vulnerabilities; 2 . Identify future vulnerabilities; 3. Identify adaptation options; 4 . Assess adaptation options; 5 . Integrate, monitor and review. It was a pioneering project in Portugal in the area of adaptation to climate change that involved 27 national municipalities in the creation of their strategies.

The municipal strategies resulted from an interactive process between the municipal technicians and the project's scientific team. The municipal technical team (EMAAC coordinating team) received specific training on the application of the methodology and all work was monitored and supported by the external team of the ClimAdaPT.Local project.

The first intermunicipal plans were presented in 2017, following the implementation of the Operational Program for Sustainability and Efficiency in the Use of Resources (POSEUR, acronym in Portuguese) approved by the EC (2014) whose specific objective is investment priority 5.1-o "Investment support for adaptation to climate change, including ecosystem-based approaches" (https:// poseur.portugal2020.pt/en/investmentaxes/axis-ii/, accessed on 22 February 2021). The intermunicipal plans were developed and coordinated by consortia that include research teams (academia) and/or companies private with the collaboration of the municipalities; not all of them have the same structure or the same details, with differences in the level of development of those presented in 2017 to 2019, but it can be said that the ADAM methodology also influenced their construction.

Within the scope of municipal strategies and intermunicipal plans, workshops were held with stakeholders in order to involve local communities with strategic documents.

A list of the documentation that was analyzed is provided in Appendix A.

\subsection{Analysis of Strategies and Plans}

After selecting the documents, common sections were selected in order to analyze their content. These sections represent thematically different (context) parts of the strategies and plans (Figure 1).

The analysis of the documents (EU's adaptation strategy, municipal strategies and intermunicipal plans) was carried out in two stages:

- Quantitative content analysis based on EbA keywords (words used to describe EbA from the literature review) - ecosystem-based, ecosystem, ecosystem service, environmental service, biodiversity, biological diversity, green infrastructure, green structure [18] and green area-and comparison with the quantitative content analysis, based on the EbA keywords, of the EU Adaptation Strategy (2013). The EU Adaptation Strategy comprises a set of documents that were analyzed (COM216, SWD131, SWD133, SWD136, SWD137, SWD138, COM213) (https://ec.europa.eu/ clima/policies/adaptation/what_en\#tab-0-1, accessed on 22 February 2021) excluding documents referring to technical guides and guidelines SWD134, SWD135, SWD139 and SWD132. Each document was analyzed for the presence of keywords and the number of mentions was quantified.

Knowing that the EbA concept includes components such as biodiversity, ecosystem services and adaptation to climate change, we sought to know the degree to which the EbA concept is used in strategic documents. Thus, the keywords were classified according to their form of reference to the EbA concept: explicit, direct references to the term "ecosystembased" were understood as evidence of the conscious adoption of the concept, and implicit, indirect references (terms that describe underlying concepts such as ecosystem services, biodiversity) were understood as a conceptual understanding of the related objectives and benefits [19] (Figure 1). 
- Analysis of the EbA keywords context, associating the EbA keywords to the thematic section identified in the analyzed documents in order to identify in which context they are used. In this sense, the quantification of the number of mentions is used for each of the EbA keywords inserted in the thematic sections identified in the strategic documents. The thematic sections that were identified in the documents are: general context (framing the theme of climate change, local characterization), objectives (objectives and strategic vision), climate change (cc) impact/vulnerability (projected climate changes; observed and projected climate impacts and vulnerabilities) and adaptation options (adaptation options that allow responding to vulnerabilities and climate risks-current and future). Comparison with the EU's adaptation strategy (2013).

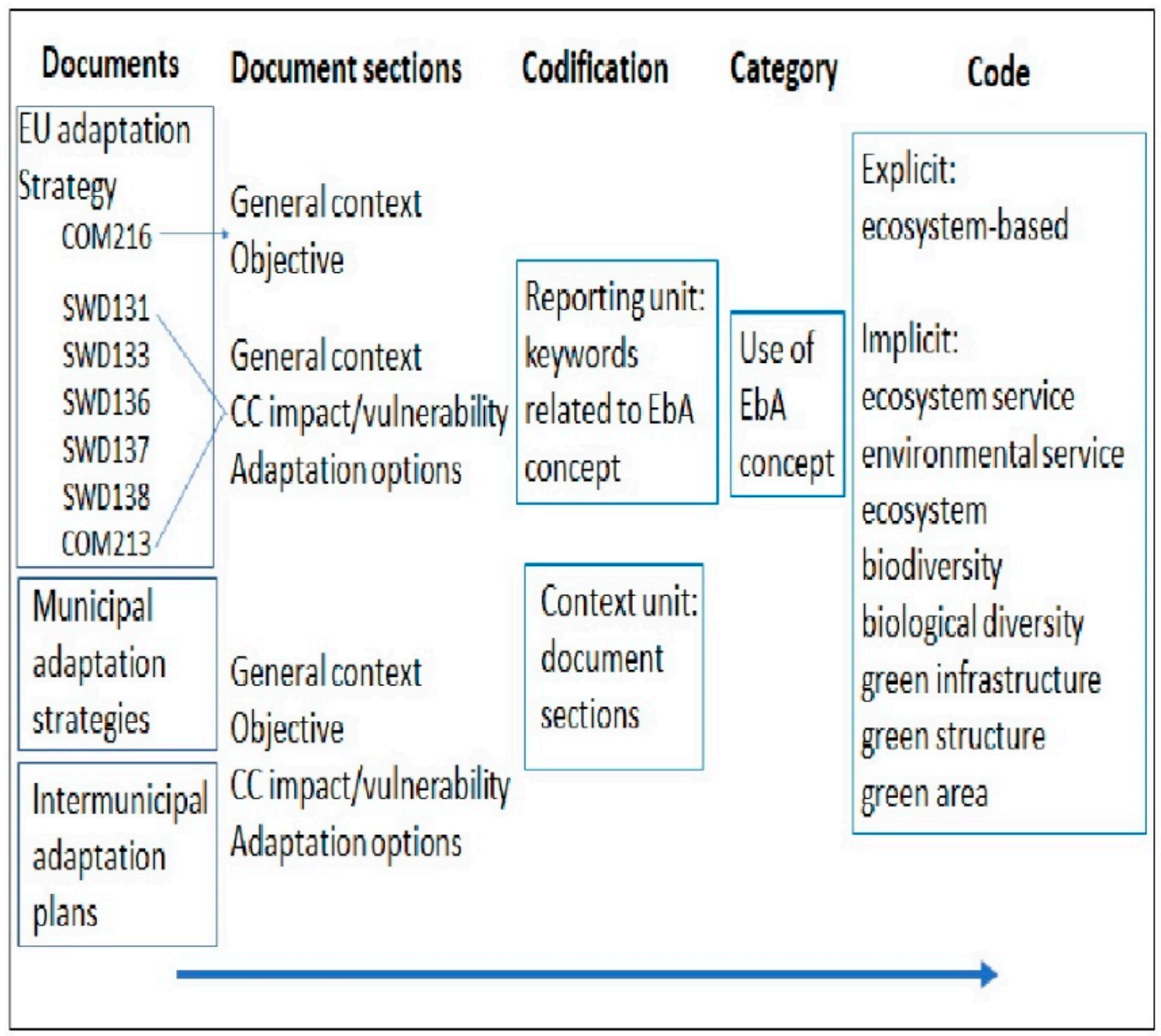

Figure 1. Procedures used for content analysis, from left to right.

\section{Results}

The term "ecosystem-based" appears to be explicitly referred to in the EU strategy (13\% of all related mentions); however, at the national level, this expression has not been transposed to municipal strategies, being discreetly mentioned $(0.8 \%)$ in intermunicipal plans (Figure 2). 


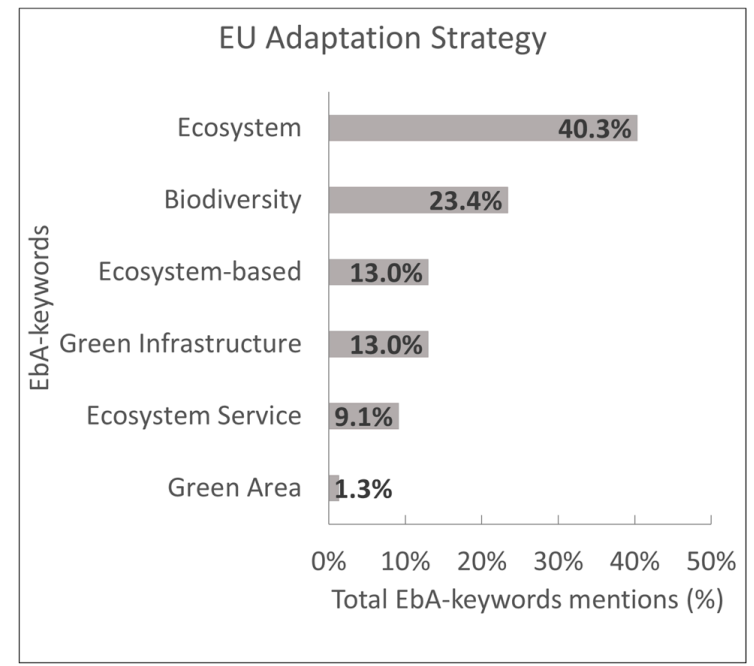

(a)

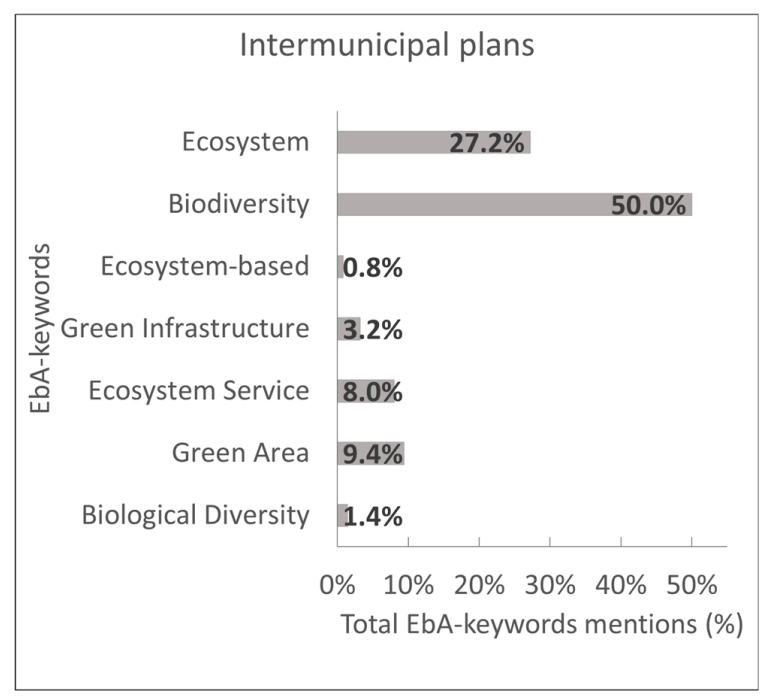

(c)

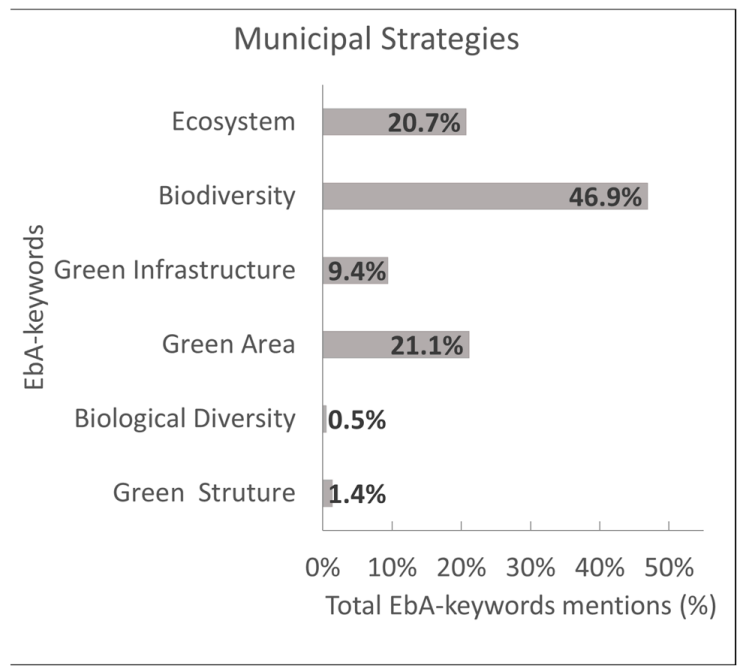

(b)

Figure 2. Percentage of total mentions for each EbA related keywords per set of analyzed documents, (a) EU's adaptation strategy, $\mathrm{N}_{\text {keywords }}=77$, (b) municipal strategies, $\mathrm{N}_{\text {keywords }}=759$ and (c) intermunicipal plans, $\mathrm{N}_{\text {keywords }}=784$. The EbA-keywords with zero mentions appear absent in the graphs.

All strategies and plans included indirect references to the components underlying the concept of EbA, reflected in the use of related keywords, namely "ecosystem", "biodiversity" with emphasis, "green area" and "green infrastructure" with less expression. However, the term "ecosystem service", although closely related to EbA, receives attention only in intermunicipal plans (PIAAC) and is absent from municipal strategies (EMAACs) (Figure 2).

Considering, in the context analysis, only keywords with more than $1 \%$ representation, the term "ecosystem-based" appears as an explicit objective of the EU strategy and associated with the contexts of climate change impacts and adaptation options (Figure 3).

In the analyzed strategies and plans, the term "ecosystems-based" occurs neither as an explicit objective nor with representativeness in the contexts of climate change impacts and adaptation options. Looking from a time perspective, six years after the publication of the EU Adaptation Strategy (2013), there are no references to ecosystem-based adaptation as an explicit objective in strategic adaptation planning at the local level (Figure 3).

In relation to the other keywords, there is an explicit absence in the objectives of the strategies and plans in relation to the EU strategy (2013). The references "biodiversity" and 
"ecosystem" have been included in the context of climate change impacts and adaptation options, while "green area" and "green infrastructure" appear essentially associated with the context of adaptation options. The transposition of the reference "ecosystem service" followed a similar pattern at the intermunicipal level in relation to the EU strategy, being absent at the municipal level (Figure 3).

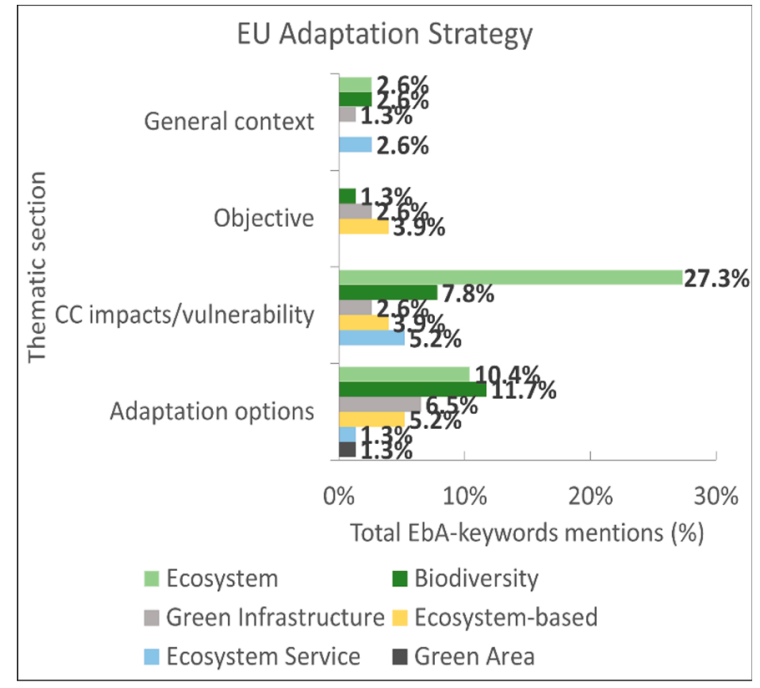

(a)

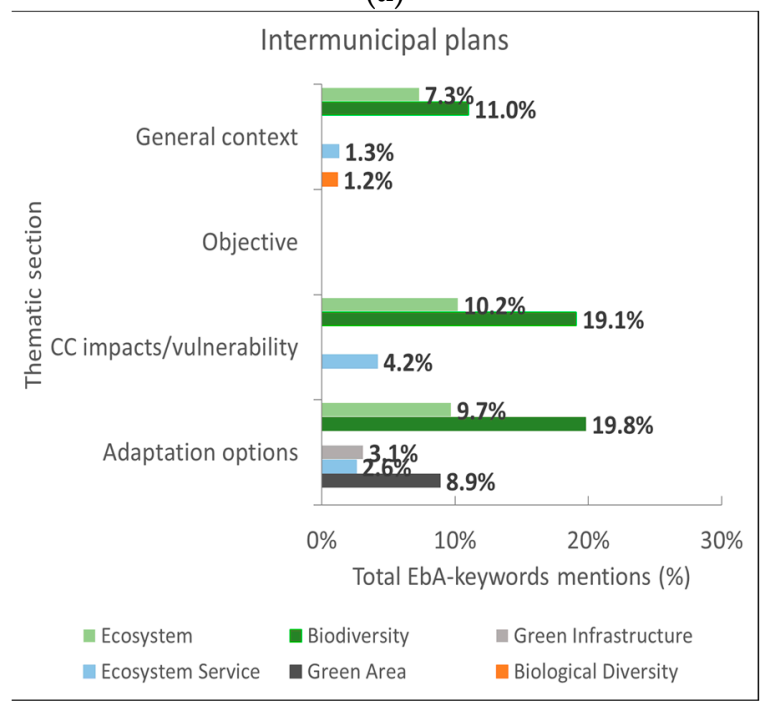

(c)

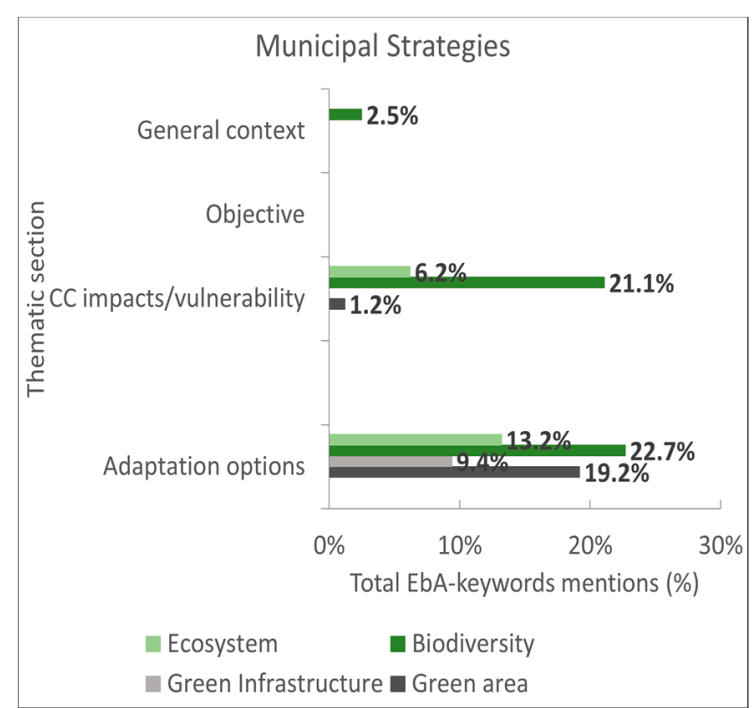

(b)

Figure 3. Percentage of total mentions for each EbA-keyword associated with the thematic sections identified in the documents, (a) EU's adaptation strategy, $\mathrm{N}_{\text {keywords }}=77$, (b) municipal strategies, $\mathrm{N}_{\text {keywords }}=759$ and (c) intermunicipal plans, $\mathrm{N}_{\mathrm{keywords}}=784$. Only keywords with more than $1 \%$ representation.

With a focus on the differences between the municipal strategies and intermunicipal plans, it should be noted that they result from different preparation processes and their authors have different backgrounds. In municipal strategies (EMAACs), the term "green area" stands out in the context of adaptation options. Its preparation was coordinated, in each municipality, by an internal team of technicians with different backgrounds but where the disciplinary areas associated with engineering, design and planning stand out (Figure 4). 


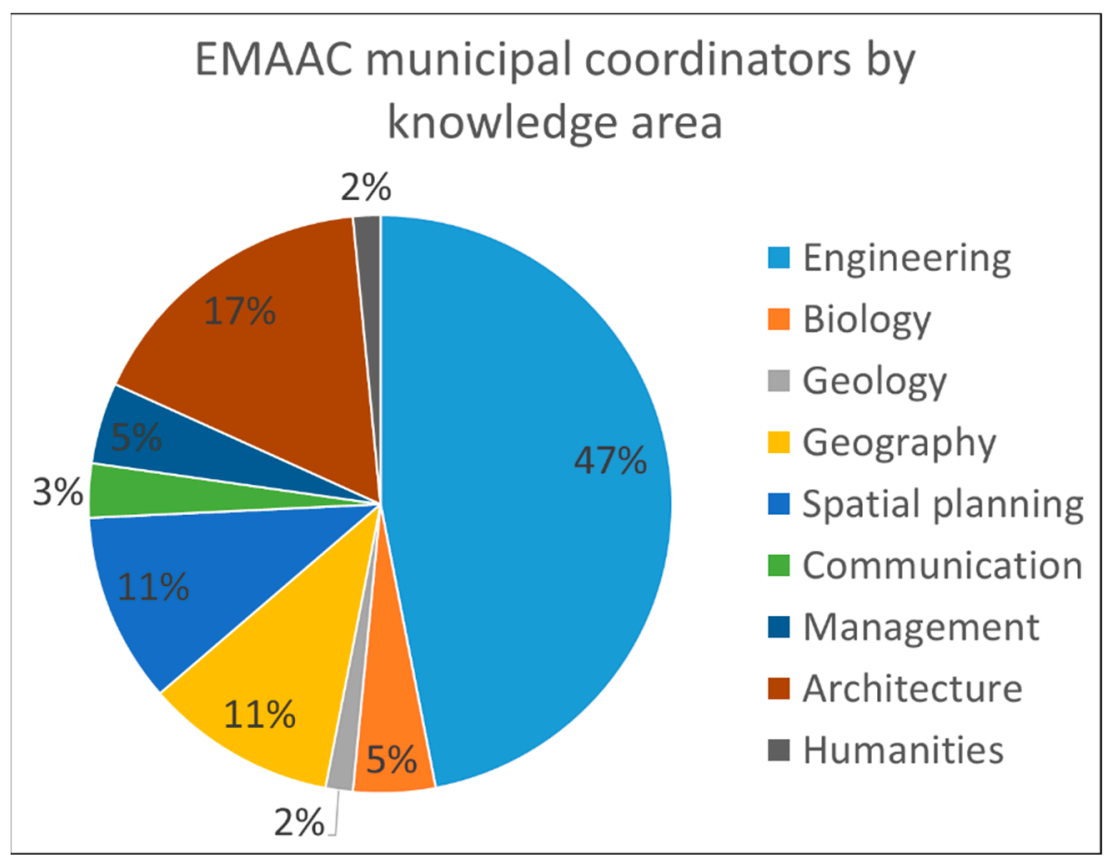

Figure 4. Municipal technicians by area of knowledge present in the coordinating teams in the municipal strategies (EMAAC), $n=66$.

The intermunicipal plans (PIAACs) benefited from the experience acquired by the ClimAdapt.Local project. Its preparation was coordinated by a consortium made up of research teams (academia) and/or consulting companies, with emphasis on the greater number of mentions of the keyword "ecosystem service" in the plans prepared by consortia that integrate the research teams (Figure 5).

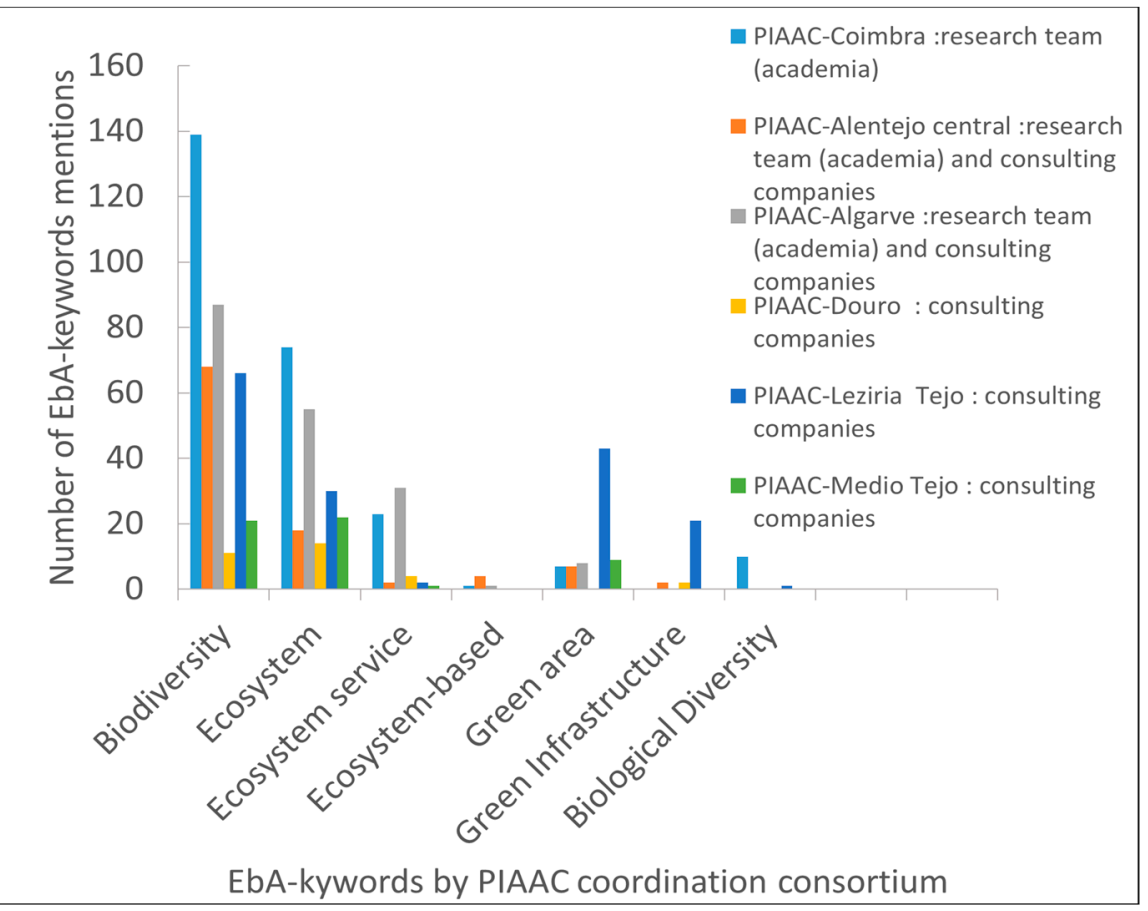

Figure 5. Number of EbA-keywords mentions in each intermunicipal plan (PIAAC) and type of PIAAC coordinating consortium (research team, research team and consulting companies), $n=6$. 


\section{Discussion}

The results of the strategies and plans were analyzed based on the objective of the EU's adaptation strategy for the adoption of EbA.

\subsection{The Use of the EbA Concept in Strategic Adaptation Planning Documents}

The EU's adaptation strategy (2013) explicitly recognizes the relevant role of EbA in adapting to climate change. However, this form has not been transposed as an explicit objective of the first municipal strategies (EMAAC) or the first intermunicipal plans (PIAAC). This can be due to the fact that The National Strategy for Adaptation to Climate Change 2020, a guiding document for local adaptation strategies, does not include EbA as an explicit objective [20]. However, most of the strategies and plans analyzed included indirect references to the underlying elements of $\mathrm{EbA}$ (ecosystems, biodiversity, green infrastructure, and green area), indicating general recognition of elements of this concept.

Regarding the underlying concept of "ecosystem service", there has been an evolution in the way the concept expresses itself from municipal strategies to intermunicipal plans in relation to the EU's adaptation strategy, which seems to result from the contribution of PIAACs prepared by consortia that include the academia (Figure 5). This relationship with academia is also seen in Germany, where, for example, Dresden's adaptation strategy that resulted from a research project entitled "REGKLAM" contains the most references to ecosystem services [18]. This observation is probably the result of the concept of "ecosystem services" being introduced by the scientific community, with great prominence in 1997 with the publications of Gretchen Daily [21] and Robert Costanza [22], but it also raises the question of the concept of "ecosystem service" being comprehensively understood outside academia. Some reasons can be exposed, namely, the coexistence of better-established concepts like "green infrastructure" in the planning discourse [23]. Perhaps that is why the term "ecosystem service" does not appear in municipal strategies in Portugal. In addition, climate change adaptation measures are often dominated by an infrastructure-based approach and, consequently, remain unrelated to ecosystem services [24]. Also, the lack of national promotion of "ecosystem services" in Portugal—as in Sweden, where "ecosystem services" were adopted by city officials, making them a key factor for nature-based planning approaches at the local level $[16,24]$ —an hinder the integration of ecosystem services in spatial planning at the local level. This difficulty is visible, for example, in the two most important legislative documents in the area of territorial management, such as the basic law of public soil policy, land-use planning and urbanism (Law No. 31/2014) (https://data.dre.pt/eli/lei/31/2014/05/30/p/dre/pt/html, accessed on 3 March 2021) and in the instruments of territorial management in 2015 (DL n ${ }^{\circ}$ 80/2015) (https:/ / data.dre.pt/eli/dec-lei/80/2015/p/cons/20201002/pt/html, accessed on 3 March 2021) where there is no concrete reference to ecosystem services.

The emphasis given to the term "biodiversity" probably results from the recognition of the importance of the impact of climate change on biodiversity in Portugal (Figure 3), as is recognized in other countries such as Germany [18]. Also, part of Portugal's commitment to European and international agreements on the conservation of nature and biodiversity is an example of the European Biodiversity Strategy 2020, the United Nations Agenda for Sustainable Development 2030 and the Convention on Biological Diversity. It is important to add that the recognition of the importance of biodiversity by Portugal has been going on for some time, with the ratification of the Convention on Biological Diversity in 1993, from where the definitions of ecosystem and biodiversity that are still the most used today emerged.

The creation of the Natura 2000 Network in Portugal also contributed to reinforcing the importance of biodiversity as it represents about $22 \%$ of its land area, average EU-28: $18 \%$ (RCM 55/2018) (https:/ / data.dre.pt/eli/resolconsmin/55/2018/05/07/p/dre/pt/html, accessed on 3 March 2021), which corresponds to $71 \%$ of the municipalities with the area classified in this scope (INE, 2016) (https://www.ine.pt/, accessed on 3 March 2021). This local expression is also visible in the strategies and plans analyzed, that is, $70 \%$ 
of the municipalities in the municipal strategies and $64 \%$ of the municipalities in the intermunicipal plans have designated areas of the Natura 2000 Network.

As for the term "green infrastructure" (GI) it appears in the EU's context as a "strategically planned network of natural and semi-natural areas with other environmental characteristics designed and managed to provide a wide range of ecosystem services" [25] (p. 3) and it is explicitly encouraging its adoption as an approach to adaptation to climate change such as EbA [6]. This relationship with the adaptation context is visible both at the level of municipal strategies and intermunicipal plans, which is not the case with the term "ecosystem-based", which may be related to the "antiquity" of the concept, GI was first introduced in the middle of the 90s [26] and has been adopted by the various disciplines related to design, conservation, and planning [27]. This trend seems compatible when we consider the areas of knowledge of the municipal technicians responsible for coordinating the EMAACs (Figure 4). Associated with the GI appears the term "green area" because they are important components of the GI and are considered public goods that allow free access to all citizens and represent grants of nature for all residents [28].

\subsection{Strengthen Explicit Adoption of the EbA Concept in Strategic Adaptation Planning}

From the analyzed documents, the strategic orientation at the European level does not seem to be sufficient for the preferential integration of EbA in strategic adaptation planning at the local and sub-regional (municipal and intermunicipal) levels in Portugal. Thus, strong leadership will be needed to promote ecosystem-based adaptation at the local and sub-regional levels, even without the support of higher levels of decision-making or supporting legislation [29]. This is the case, for example, in Lomma, Sweden, where the integration of ecosystem-based planning was made possible by local politicians who explicitly took steps to reverse the decline in green infrastructure [16,24]. It is also crucial to involve municipal officials committed to previous experience in integrating other issues at the municipal level. For example, the involvement of municipalities in environmental planning (in Germany and Sweden), their support for the concept of ecosystem services (in Sweden) or the mitigation of climate change (in Germany), enabled the structures, processes and instruments necessary to pave the way for the integration of ecosystembased adaptation at the municipal level [24].

The promotion of EbA at the local and sub-regional level could be facilitated by synergies between topics, for example, the promotion of biodiversity can motivate the use of ecosystem services to adapt to climate change. This is what happened in the municipality of Helsingborg, Sweden, where the promotion of biodiversity through green infrastructure was used to manage rainwater flows [24,30]. In addition, synergies between adaptation and mitigation of climate change can be provided by EbA. This is the case of German cities that recommend ecological measures, such as planting trees on the streets or green trails, as well as installing green facades to mitigate urban heat [31]. The greening of the facades can decrease the demand for refrigeration energy in a building [32], urban vegetation can sequester and store carbon emission [33], thus, helping to mitigate climate change. In addition, it provides various ecosystem services, such as new habitats for animals and plants [34], noise reduction [35], particle filtering and absorption of air pollutants [36].

Ecosystem-based adaptation has the potential to generate co-benefits, that is, it can help meet various environmental, social and economic objectives [37,38], in addition to helping to overcome the challenge of climate change. In this sense, the use of co-benefits could be a way of exploring to promote broader acceptance of this approach by different stakeholders, as the evidence suggests that citizens are more likely to act on climate change if the wider co-benefits of these actions are emphasized [39]. However, the co-benefits approach requires going beyond its communication, that is, including co-benefits in policy formulation and decision making [39]. In this sense, the development of tools that make it possible to measure the co-benefits of EbA options at the local level could be a way to explore to help support the decision and involve different actors in the implementation of EbA. 


\section{Conclusions}

This study found that the adoption of the EbA concept and terminology in the municipal strategies and intermunicipal plans in Portugal is influenced by the educational background, objectives and interests of the stakeholders (municipal technicians, companies, academics) involved in its elaboration.

Although the EU's adaptation strategy (2013) explicitly encourages EbA, this does not mean that it is adopted as a preferred adaptation approach at the local level in Portugal, as the strategic documents analyzed show that $\mathrm{EbA}$ is not an objective explicit. However, there is recognition of the importance of "green infrastructure" and "green spaces" for a clear adaptation to climate change and "biodiversity" and "ecosystems" in a less expressive way.

The term "ecosystem service", although closely related to EbA, receives less attention than other terms, such as "biodiversity", "ecosystems", "green infrastructure" and "green spaces", and appears to be more widely understood by the research community than by municipal technicians or private companies. This trend has consequences for the understanding of the concept of EbA, which seems to accompany this same trend, which can hinder its implementation.

Author Contributions: Conceptualization, A.C. and G.P.-L.; methodology, A.C. and G.P.-L.; investigation, A.C.; supervision, G.P.-L.; writing-original draft preparation A.C.; writing review and editing, A.C. and G.P.-L. All authors have read and agreed to the published version of the manuscript.

Funding: This research received no external funding.

Institutional Review Board Statement: Not applicable.

Informed Consent Statement: Not applicable.

Data Availability Statement: The data presented in this study are openly available in the reports of the municipal strategies and intermunicipal adaptation plans made available in Appendix A.

Acknowledgments: We would like to thank Fundação para a Ciência e Tecnologia for supporting the FCT Investigator contract (IF/00940/2015) of G.P.-L. The APC was funded by the cE3c FCT Unit funding UIDB/00329/2020.

Conflicts of Interest: The authors declare no conflict of interest.

\section{Appendix A}

Table A1. List of documents analyzed.

\begin{tabular}{|c|c|c|c|}
\hline Strategic Document Type & Name & Year & Coordination \\
\hline PIAAC & $\begin{array}{l}\text { Plano Intermunicipal de Adaptação às Alterações } \\
\text { Climáticas da CIM-Região de Coimbra } \\
\text { https:/ / www.cim-regiaodecoimbra.pt/wp- } \\
\text { content/uploads / 2018/10/PIAAC-CIM-RC-vers\% } \\
\text { C3\%A3o-web.pdf (accessed on } 8 \text { February 2021) }\end{array}$ & 2017 & $\begin{array}{l}\text { CEF and CEGOT from University } \\
\text { of Coimbra }\end{array}$ \\
\hline PIAAC & $\begin{array}{l}\text { Plano Intermunicipal de Adaptação às Alterações } \\
\text { Climáticas-Alentejo Central } \\
\text { https:/ / www.cimac.pt/wp-content/uploads / } 2020 \\
\text { /12/PIAAC_AC-Relatorio-Final.pdf (accessed on } \\
\text { 8 February 2021) }\end{array}$ & 2017 & $\begin{array}{l}\text { CEDRU_-Technical consulting } \\
\text { company } \\
\text { We Consultants (territorial } \\
\text { consultancy projects) } \\
\text { IGOT from University of Lisbon }\end{array}$ \\
\hline PIAAC & $\begin{array}{l}\text { Plano de Ação Intermunicipal para as Alterações } \\
\text { Climáticas do Douro } \\
\text { https:/ / www.cimdouro.pt/adapt_clima/files/ } \\
\text { proposta_paiac.pdf (accessed on } 8 \text { February 2021) }\end{array}$ & 2017 & $\begin{array}{l}\text { Inflection Point, Unipessoal Lda } \\
\text { (Consultancy for information } \\
\text { management, strategic planning } \\
\text { and cartography production) }\end{array}$ \\
\hline
\end{tabular}


Table A1. Cont.

\begin{tabular}{|c|c|c|c|}
\hline Strategic Document Type & Name & Year & Coordination \\
\hline PIAAC & $\begin{array}{l}\text { Plano Intermunicipal de Adaptação às Alterações } \\
\text { Climáticas-Lezíria do Tejo } \\
\text { https: / / www.cimlt.eu/pdf-s/2486-piaaclt-plano- } \\
\text { intermunicipal-de-adaptacao-alteracoes-climaticas- } \\
\text { lt/ file (accessed on } 8 \text { February 2021) }\end{array}$ & 2018 & $\begin{array}{c}\text { PROCESL (company specialized } \\
\text { in consulting) } \\
\text { Matos, Fonseca \& Associados, } \\
\text { Estudos e Projectos, Lda. } \\
\text { (Environmental studies and } \\
\text { projects company) }\end{array}$ \\
\hline PIAAC & $\begin{array}{l}\text { Plano Intermunicipal de Adaptação às Alterações } \\
\text { Climáticas-Médio do Tejo } \\
\text { https:/ / mediotejo.pt/images/CIMT / Areas_de__ } \\
\text { Intervencao/Alteracoes-Climaticas/PIAAC_MT_- } \\
\text { Final.pdf(accessed on } 8 \text { February 2021) }\end{array}$ & 2018 & $\begin{array}{c}\text { Enhidrica company } \\
\text { (environmental engineering } \\
\text { consultancy) }\end{array}$ \\
\hline PIAAC & $\begin{array}{l}\text { Plano Intermunicipal de Adaptação às Alterações } \\
\text { Climaticas do Algarve } \\
\text { https:/ / amal.pt/comunicacao/publicacoes / 234- } \\
\text { plano-intermunicipal-de-adaptacao-as-alteracoes- } \\
\text { climaticas-piaac-amal (accessed on } 8 \text { February 2021) }\end{array}$ & 2019 & $\begin{array}{c}\text { CCIAM/cE3c/Faculty of Sciences } \\
\text { University of Lisbon } \\
\text { CIMA/University Algarve } \\
\text { Bentley Systems Portugal } \\
\text { (software solutions for } \\
\text { engineering and infrastructure) }\end{array}$ \\
\hline EMAAC & $\begin{array}{l}\text { Estratégia Municipal de Adaptação às Alterações } \\
\text { climáticas de: } \\
\text { Amarante, Barreiro, Braga, Bragança, Castelo Branco, } \\
\text { Castelo de Vide, Coruche, Evora, Ferreira do } \\
\text { Alentejo, Figueira da Foz, Funchal, Guimarães, } \\
\text { Ilhavo, Leiria, Lisboa, Loulé, Mafra, Montalegre, } \\
\text { Odemira, Porto, São João da Pesqueira, Seia, Tomar, } \\
\text { Tondela, Torres Vedras, Viana do Castelo, Vila } \\
\text { Franca do campo. } \\
\text { https: / / apambiente.pt/index.php?ref=16\&subref= } \\
\text { 81\&sub2ref=118\&sub3ref=395 (accessed on } \\
\text { 8 February 2021) }\end{array}$ & 2016 & $\begin{array}{l}\text { Municipal technicians with } \\
\text { support from the } \\
\text { ClimAdapt.Local project }\end{array}$ \\
\hline
\end{tabular}

\section{References}

1. Secretariat of the Convention on Biological Diversity. Connecting Biodiversity and Climate Change Mitigation and Adaptation: Report of the Second Ad Hoc Technical Expert Group on Biodiversity and Climate Change. Available online: https:/ /www.cbd. int/doc/publications/cbd-ts-41-en.pdf (accessed on 18 May 2021).

2. Hannah Reid, M.A. Community-Based Adaptation to Climate Change: An Overview (PLA 60). Available online: https: //pubs.iied.org/G02608 (accessed on 8 February 2021).

3. Heenan, A.; Gorospe, K.; Williams, I.; Levine, A.; Maurin, P.; Nadon, M.; Oliver, T.; Rooney, J.; Timmers, M.; Wongbusarakum, S.; et al. Ecosystem Monitoring for Ecosystem-Based Management: Using a Polycentric Approach to Balance Information Trade-Offs. J. Appl. Ecol. 2016, 53, 699-704. [CrossRef]

4. Jones, H.P.; Hole, D.G.; Zavaleta, E.S. Harnessing Nature to Help People Adapt to Climate Change. Nat. Clim. Chang. 2012, 2, 504-509. [CrossRef]

5. Munang, R.; Thiaw, I.; Alverson, K.; Goumandakoye, M.; Mebratu, D.; Liu, J. Using Ecosystem-Based Adaptation Actions to Tackle Food Insecurity. Environment 2013, 55, 29-35. [CrossRef]

6. EC. Communication from the Commission to the European Parliament, the, Council, the European Economic and Social Committee and the Committee of the Regions. An EU Strategy on Adaptation to Climate Change. COM (2013) 216, Brussels. 2013. Available online: https:/ / ec.europa.eu/transparency/regdoc/rep/1/2013/EN/1-2013-216-EN-F1-1.Pdf (accessed on 8 February 2021).

7. EC. Communication from the Commission to the European Parliament, the, Council, the European Economic and Social Committee and the Committee of the Regions. The European Green Deal. COM (2019) 640 final, Brussels. 2019. Available online: https:/ / eur-lex.europa.eu/legal-content/EN/TXT/?uri=COM:2019:640:FIN (accessed on 8 February 2021).

8. Cecchi, C. Towards an EU Research and Innovation Policy Agenda for Nature-Based Solutions E Re-Naturing Cities; Final Report of the Horizon 2020 Expert Group on Nature-Based Solutions and Re-Naturing Cities; Publications Office of the European Union: Luxembourg, 2015. [CrossRef] 
9. FEBA (Friends of Ecosystem-based Adaptation). Making Ecosystem-Based Adaptation Effective: A Framework for Defining Qualification Criteria and Quality Standards (FEBA Technical Paper Developed for UNFCCC-SBSTA 46); Bertram, M., Barrow, E., Blackwood, K., Rizvi, A.R., Reid, H., von Scheliha-Dawid, S., Eds.; GIZ: Bonn, Germany; IIED: London, UK; IUCN: Gland, Switzerland, 2017; p. 14. Available online: https://pubs.iied.org/sites/default/files/pdfs/migrate/G04167.pdf (accessed on 8 February 2021).

10. Aguiar, F.C.; Bentz, J.; Silva, J.M.N.; Fonseca, A.L.; Swart, R.; Santos, F.D.; Penha-Lopes, G. Adaptation to Climate Change at Local Level in Europe: An Overview. Environ. Sci. Policy 2018, 86, 38-63. [CrossRef]

11. Measham, T.G.; Preston, B.L.; Smith, T.F.; Brooke, C.; Gorddard, R.; Withycombe, G.; Morrison, C. Adapting to Climate Change through Local Municipal Planning: Barriers and Challenges. Mitig. Adapt. Strateg. Glob. Chang. 2011, 16, 889-909. [CrossRef]

12. Picketts, I.M.; Déry, S.J.; Curry, J.A. Incorporating Climate Change Adaptation into Local Plans. J. Environ. Plan. Manag. 2014, 57, 984-1002. [CrossRef]

13. Climate Adapt. Adaptation Strategies for European Cities Final Report. Available online: https://climate-adapt.eea.europa.eu/ repository/11156095.pdf/view (accessed on 18 May 2021).

14. Vignola, R.; Locatelli, B.; Martinez, C.; Imbach, P. Ecosystem-Based Adaptation to Climate Change: What Role for Policy-Makers, Society and Scientists? Mitig. Adapt. Strateg. Glob. Chang. 2009, 14, 691. [CrossRef]

15. Brink, E.; Aalders, T.; Ádám, D.; Feller, R.; Henselek, Y.; Hoffmann, A.; Ibe, K.; Matthey-Doret, A.; Meyer, M.; Negrut, N.L.; et al. Cascades of Green: A Review of Ecosystem-Based Adaptation in Urban Areas. Glob. Environ. Chang. 2016, 36, 111-123. [CrossRef]

16. Wamsler, C.; Pauleit, S. Making Headway in Climate Policy Mainstreaming and Ecosystem-Based Adaptation: Two Pioneering Countries, Different Pathways, One Goal. Clim. Chang. 2016, 137, 71-87. [CrossRef]

17. Busch, C.; Paul, S.; Maret, D.; Flynn, T.; Kellum, R.; Le, S.; Meyers, B.; Saunders, M.; White, R.; Palmquist, M. Content Analysis. (1994-2012) Writing@CSU. Colorado State University. Available online: https:/ /writing.colostate.edu/guides/pdfs/guide61.pdf (accessed on 18 February 2021).

18. Zölch, T.; Wamsler, C.; Pauleit, S. Integrating the Ecosystem-Based Approach into Municipal Climate Adaptation Strategies: The Case of Germany. J. Clean. Prod. 2018, 170, 966-977. [CrossRef]

19. Hansen, R.; Frantzeskaki, N.; McPhearson, T.; Rall, E.; Kabisch, N.; Kaczorowska, A.; Kain, J.-H.; Artmann, M.; Pauleit, S. The Uptake of the Ecosystem Services Concept in Planning Discourses of European and American Cities. Ecosyst. Serv. 2015, 12, 228-246. [CrossRef]

20. Agência Portuguesa do Ambiente. Estratégia Nacional de Adaptação às Alterações Climáticas (ENAAC 2020). Consulta_publica. 2015. Available online: https://www.dge.mec.pt/sites/default/files/ECidadania/Educacao_Ambiental/documentos/enaac_ consulta_publica.pdf (accessed on 10 February 2021).

21. Daily, G.C. Nature's Services: Societal Dependence On Natural Ecosystems; Island Press: Washington, DC, USA, 1997.

22. Costanza, R.; dArge, R.; de Groot, R.; Farber, S.; Grasso, M.; Hannon, B.; Limburg, K.; Naeem, S.; Oneill, R.V.; Paruelo, J.; et al. The value of the world's ecosystem services and natural capital. Nature 1997, 387, 253-260. [CrossRef]

23. Albert, C.; Haaren, C.; Galler, C. Ökosystemdienstleistungen-Alter Wein in Neuen Schläuchen Oder Impuls Für Die Landschaftsplanung. Nat. Landsch. 2012, 44, 142-148.

24. Wamsler, C.; Luederitz, C.; Brink, E. Local Levers for Change: Mainstreaming Ecosystem-Based Adaptation into Municipal Planning to Foster Sustainability Transitions. Glob. Environ. Chang. 2014, 29, 189-201. [CrossRef]

25. EC, European Commission. Communication from the Commission to the European Parliament, The Council, the European Economic and Social Committee and the Committee of the Regions. Green Infrastructure (GI)—Enhancing Europe's Natural Capital. COM (2013) 249 Fina. Available online: https: / / eur-lex.europa.eu/resource.html?uri=cellar:d41348f2-01d5-4abe-b817-4 c73e6f1b2df.0014.03/DOC_1\&format=PDF (accessed on 11 February 2021).

26. Pauleit, S.; Liu, L.; Ahern, J.; Kazmierczak, A. Multifunctional Green Infrastructure Planning to Promote Ecological Services in the City; Oxford University Press: Oxford, UK, 2011.

27. European Environment Agency. Green Infrastructure and Territorial Cohesion: The Concept of Green Infrastructure and Its Integration into Policies Using Monitoring Systems. EEA Technical Report No. 18/2011. Available online: https:/ /www.eea. europa.eu/themes/publications/green-infrastructure-and-territorial-cohesion (accessed on 11 February 2021).

28. De La Barrera, F.; Reyes-Paecke, S.; Banzhaf, E. Indicators for Green Spaces in Contrasting Urban Settings. Ecol. Indic. 2016, 62, 212-219. [CrossRef]

29. Roberts, D. Prioritizing Climate Change Adaptation and Local Level Resilience in Durban, South Africa. Environ. Urban. 2010, 22, 397-413. [CrossRef]

30. Wamsler, C.; Niven, L.; Beery, T.; Bramryd, T.; Ekelund, N.; Jönsson, K.I.; Osmani, A.; Palo, T.; Stålhammar, S. Operationalizing Ecosystem-Based Adaptation: Harnessing Ecosystem Services to Buffer Communities against Climate Change. Ecol. Soc. 2016, 21, 31. [CrossRef]

31. Sprondel, N.; Donner, J.; Mahlkow, N.; Köppel, J. Urban Climate and Heat Stress: How Likely Is the Implementation of Adaptation Measures in Mid-Latitude Cities? The Case of Façade Greening Analyzed with Bayesian Networks. One Ecosyst. 2016, 1, e9280. [CrossRef]

32. Perini, K.; Ottelé, M.; Fraaij, A.L.A.; Haas, E.M.; Raiteri, R. Vertical Greening Systems and the Effect on Air Flow and Temperature on the Building Envelope. Build. Environ. 2011, 46, 2287-2294. [CrossRef]

33. Velasco, E.; Roth, M. Cities as Net Sources of CO2: Review of Atmospheric CO2 Exchange in Urban Environments Measured by Eddy Covariance Technique. Geogr. Compass 2010, 4, 1238-1259. [CrossRef] 
34. Solecki, W.D.; Rosenzweig, C. Biodiversity, Biosphere Reserves, and the Big Apple: A Study of the New York Metropolitan Region. Ann. N. Y. Acad. Sci. 2004, 1023, 105-124. [CrossRef] [PubMed]

35. Van Renterghem, T.; Botteldooren, D. Reducing the Acoustical Façade Load from Road Traffic with Green Roofs. Build. Environ. 2009, 44, 1081-1087. [CrossRef]

36. Escobedo, F.J.; Kroeger, T.; Wagner, J.E. Urban Forests and Pollution Mitigation: Analyzing Ecosystem Services and Disservices. Environ. Pollut. 2011, 159, 2078-2087. [CrossRef] [PubMed]

37. Naumann, S.; Anzaldua, G.; Berry, P.; Burch, S.; Davis, M.; Frelih-Larsen, A.; Gerdes, H.; Sanders, M. Assessment of the Potential of Ecosystem-Based Approaches to Climate Change Adaptation and Mitigation in Europe; Final Report to the European Commission, DG Environment. Contract No. 070307/2010/580412/ SER/B2; Ecologic Institute and Environmental Change Institute, Oxford University Centre for the Environment: Oxford, UK, 2011; p. 128.

38. Salata, K.-D.; Yiannakou, A. The Quest for Adaptation through Spatial Planning and Ecosystem-Based Tools in Resilience Strategies. Sustainability 2020, 12, 5548. [CrossRef]

39. Bain, P.G.; Milfont, T.L.; Kashima, Y.; Bilewicz, M.; Doron, G.; Garðarsdóttir, R.B.; Gouveia, V.V.; Guan, Y.; Johansson, L.-O.; Pasquali, C.; et al. Co-Benefits of Addressing Climate Change Can Motivate Action around the World. Nat. Clim. Chang. 2016, 6, 154-157. [CrossRef] 